\author{
Agnieszka OCIEPA-KUBICKA ${ }^{1}$ \\ T. NITKIEWICZ ${ }^{2}$ \\ P. PACHURA ${ }^{3}$ \\ B. SKOWRON-GRABOWSKA ${ }^{4}$
}

\title{
POSSIBILITIES AND LIMITATIONS OF THE ECO-INNOVATION IMPLEMENTATION IN SMALL ENTERPRISES
}

\begin{abstract}
An analysis of the levels of innovation leads to the conclusion that, still, a big problem, especially for small businesses, is the cost of their implementation. This statement is reflected in the results of quantitative and qualitative research that was presented in the article. Poor financial situation of enterprises, especially small and medium-sized, fragmented financing projects in the field of environmental protection, unstable financial conditions, lack of marketing skills and the fear and reluctance to bear the risks associated with taking innovative projects are fundamental barriers to the introduction of eco-innovation. Among the institutional barriers the following are observed: substantive and systemic weaknesses in the effective use of aid funds, and insufficient knowledge about patents, copyright, etc. It should be emphasized that small companies, introducing new solutions, depend to a large extent on the attitude of the entrepreneur. It is the entrepreneur who bears the burden of creating ideas, stimulating the employees to be active and preparing the company to implement innovative solutions.

The analysis of the literature indicates that in order to overcome barriers to the implementation of eco-innovation, action should be taken primarily in terms of raising the awareness of the need for eco-innovation. Proper environmental management also requires new instruments and procedures to improve the introduction of the environmentally friendly solutions by entrepreneurs.
\end{abstract}

Keywords: innovation, small businesses, barriers, environmental management, proecological actions.

\section{INTRODUCTION}

Economic development is closely related to the higher and higher influence of enterprises on the natural environment. The growing number of companies often interfering with environment requires the implementation of additional pro-ecological actions. Modern companies should be managed strategically, economically and innovatively. In

\footnotetext{
1 PhD Agnieszka Ociepa-Kubicka, Faculty of Management, Czestochowa University of Technology, Częstochowa, Armii Krajowej 19 B, e-mail:agnieszkaociepa22@wp.pl (corresponding author)

${ }^{2}$ Prof. T. Nitkiewicz, Faculty of Management, Czestochowa University of Technology, Częstochowa, Armii Krajowej 19 B,e-mail: tomaszn@zim.pcz.pl

${ }^{3}$ Prof. P. Pachura, Faculty of Management, Czestochowa University of Technology, Częstochowa, Armii Krajowej 19 B, e-mail: ppachura@zim.pcz.pl

${ }^{4}$ Prof. B.Skowron-Grabowska , Faculty of Management, Czestochowa University of Technology, Częstochowa, Armii Krajowej 19 B, e-mail: beatas@zim.pcz.czest.pl
} 
order to make their products competitive on markets, they have to take care of their quality which, in turn, requires openness to changes.

Vast implementation of ecological solutions may help in the restriction of many key issues related to the environmental protection, such as detrimental climate changes, decreasing natural resources, environment pollution or the loss of biological diversity.

Therefore, the introduction and use of the environment protecting regulations is so important. Their scope in different countries is regulated by adequate acts of law.

Entrepreneurs may introduce additional actions diminishing their companies' negative influence on the environment. Such actions may be realised in the field of products' manufacture, applied processes and technologies, as well as, organisation. However, research studies emphasise the hindrances of their implementation and the lack of awareness among the entrepreneurs, especially those of small and medium-size companies, and of the extent to which their company interferes with the environment. Therefore, quite often, environmental issues in companies are marginalised.

Taking the above into consideration, it seems obvious that the implementation of the environment protection solutions is indispensable.

In small and medium-size Polish companies, low level of the innovations' implementation is observed, which is a worrying phenomenon, as their activities are of priority in the local development planning. It should be emphasized that the Polish small and medium-size enterprises (SME) account for about $47-48 \%$ of the country's GDP, in this way concentrating the basic part of the production process 5 .

The aim of the article is to signalise the importance of the eco-innovation implementation as indispensable for the realisation of the environment protection requirements and for the development of companies' competitiveness. The article identifies the benefits and obstacles of the eco-innovation implementation. It also analyses the factors influencing the restrictions of new solutions' implementation, in particular, in small Polish companies.

\section{THE NOTION OF ECO-INNOVATION}

The notion of eco-innovation first appeared in 1990s in relation to the growth of ecological problems, environmental dangers and appreciation of the importance of innovative solutions for the competitiveness and economic development. Research studies and implementation of eco-innovation being the combination of innovative solutions with the care of the natural environment became indispensable for the appropriate development of the contemporary economy. The term "eco-innovation" refers to various forms of innovation which create opportunities for companies and bring benefits to the environment, mainly thanks to the prevention or restriction of their negative impact on the environment.

The notion of ecological innovation is relatively new. In Poland, only in 2009, the Central Statistical Office of Poland (GUS), comprehensively and for the first time, defined the term of eco-innovation and, simultaneously, introduced the relevant research results.

And thus, quoting after GUS, "an innovation bringing benefits to the environment (eco-innovation) is a new or improved product (a manufacture or service), process, organisational or marketing method, which brings benefits to the environment as

${ }^{5}$ Żohnierski A. Report on the states of SME in Poland in the years 2007-2008, Polish Agency for Enterprise, Warsaw 2009. 
compared to the alternative solutions." One of the first definitions of eco-innovation was suggested by Fussler and James (1996), who described it as such innovations which bring benefits to both the entrepreneur and the consumer with the simultaneous limitation of the detrimental impact of economy on the environment ${ }^{6}$. In a broad sense, eco-innovation is perceived as any innovation which improves the effectiveness of the natural resources usage in economy and minimizes the negative influence of economic processes on the natural environment ${ }^{7}$. According to Reid and Miedziński (2008), a pro-ecological innovation is any innovation realized according to the current laws and regulations in force, which bring benefits to the natural environment - especially as the minimised use of natural resources per unit of manufactured product or minimising the flow of dangerous substances into the environment in the process of the product manufacture, during and after its usage ${ }^{8}$. Eco-innovations may be created in the fields of new, eco-friendly services, products and processes, as well as, modern management methods diminishing the negative impact of companies on the environment.

The definitions explicitly indicate that apart from the limitations of the detrimental effect of the economic processes on the environment, what is also crucial is the productive use of natural environment resources. Therefore, beside the ecological dimension, the economical factor must be emphasised, too, e.g. the cost reduction and the safety issues, like diminishing the dependence on the resources deliveries. The main function of the innovative solutions is alleviating the anthropogenic effects of the environmental changes, for instance, the effects of climatic changes and the necessity of restrictions.

\section{PURPOSE AND BENEFITS OF ECO-INNOVATION IMPLEMENTATION}

Eco-innovations are strictly related to the ways of the natural resources use, to the production technologies and management methods. Nowadays, eco-innovations should be an important element of ecological policy being crucial as the environment protection prerequisites and in order to build economic competitiveness. They favour the process of production the companies' transition from traditional to modern production methods and give them competitive advantage. The introduction of eco-innovation in economic practice means the implementation of new or improved product, service or process, as well as, the implementation of a new marketing or organisation method concerning the organisation of work or relations with the environment.

Numerous authors underline that the implementation of eco-innovations contributes to the ${ }^{9}$ :

- creation of the companies' positive image,

- protection of the natural environment,

- competitiveness and economy acceleration,

- financial benefits for entrepreneurships,

- improvement of the products' and services' quality.

\footnotetext{
${ }^{6}$ Fussler C., James P., Eco-innovation: A Breakthrough Discipline for Innovation and Sustainability, Pitman Publishing, London 1996

${ }^{7}$ Kalinowski T. B., Entrepreneurships' Management and Quality Management Systems, Wolters Kluwer, Warszawa 2010.

${ }^{8}$ Reid A., Miedziński M., Eco-innovation. Final Report for sectoral innovation watch, Technopolis Group. 2008.

${ }^{9}$ Kanerva M., Arundel A., Kemp R., Environmental innovation: Using qualitative models to identify indicator for policy, United Nations University Working Papers Series, Maastricht 2009
} 
An innovation usage should result in the cost reduction and increase of sales, or the improvement of services and meeting more and more restrictive legal requirements concerning environment protection. The activities limiting companies' negative impact on environment may be carried out in the field of products manufacturing, used processes and technologies and within the scope of the organisation.

The examples of the most crucial actions regarding products, processes and technologies comprise the following:

- designing technological processes and products as regards the energy and material consumption restrictions,

- implementation of technologies and products limiting water consumption,

- implementation of renewable energy sources,

- implementation of optimal waste management methods with the assumption of the pollutant emission restriction.

Among the examples of particular solutions contributing to gradual reduction of environmental burdens there are ${ }^{10}$ :

- implementation of solar panels for water and room heating,

- improvement of material supply planning in order to reduce excess supply,

- elimination of the need of air conditioning through adequate room design,

- reduction of energy use by means of automatic solutions regulating the optimal energy use,

- organisation of various waste collection and packaging, and their delivery to recycling companies,

- optimisation of manufacture and processes design, limiting their energy and material consumption to necessary minimum,

- introduction of additional installations allowing for water cleaning (with the aim of its reuse).

Companies organisation may require ${ }^{11}$ :

- management systems, based on ISO 14001 or EMAS norms, which concern voluntary participation in European system of pro-environmental actions (audits, balances, verifications, adherence to the law, governmental support of the actions, etc.),

- implementation of intelligent systems of measurement, which bring consumer benefits such as less frequent electrical energy prices rises.

Considering the benefits for the environment, it has to be emphasised that they have to be the main objective of innovations or the effect of the undertaken actions for the realisation of other plans. They may be generated in the process of product or service manufacture or at the time of the product or service use by the consumer.

The most important benefits at the level of product or service generation are:

- lowering the material consumption per product unit,

- decrease of companies' detrimental emissions,

- the use of less pollutant or less dangerous resources for the environment,

- reduction of soil, water and air pollution,

\footnotetext{
${ }^{10}$ Grudzewski M.W., Hajduk I.K., Technology Management. Advanced Technologies and their Commercialisation, Difin, Warszawa 2008.

${ }^{11}$ Łunarski J. (ed.), Environment Management Systems, Technical University of Rzeszow Publishing House, Rzeszow 2010.
} 
- reuse of wastes, water or materials.

Therefore, after the implementation of such innovations, an enterprise may obtain savings stemming from lower water and energy use, from the decrease of waste amounts produced, from the amelioration of the effective use of resources, lowering of bills for the economic use of the environment, etc.

On the other hand, the group of benefits of a product or service use include:

- lower amounts of energy used during the exploitation period,

- lower air, water and soil pollution or noise levels,

- improvement of re-usage possibilities for particular products after the usage period.

As a result, the eco-innovations may help as solutions within the field of environment protection in numerous key issues, such as ${ }^{12},{ }^{13}$ :

- negative climate changes,

- diminishing of natural resources,

- loss of biological diversity,

- air pollution,

- waste and sewage management, recycling,

- high $\mathrm{CO}_{2}$ levels.

Taking the above benefits into consideration, companies should be managed strategically, innovatively and with the market in mind. For their products to be competitive, the companies have to take care of the quality of products, and this, in turn, demands changes. Numerous authors emphasise that the necessary condition for innovations implementation must always be the entrepreneurs who are open to non-standard environmental solutions. ${ }^{14}, 15$

\section{FACTORS INFLUENCING THE ECO-INNOVATION DEVELOPMENT IN ENTERPRISES}

As mentioned above, eco-innovations in enterprises may be realised in various fields. They may be directed at new products, processes, technologies or new management methods.

A detailed eco-innovation typology, referring to the division of the European system of innovations analysis, is suggested by the authors of the report on the MEI Project. It includes the following ${ }^{16}$ :

- environmental technologies (environmental technologies) - comprising technologies used for limitation and control of the emitted pollution and technologies restricting the use of resources and materials in production,

\footnotetext{
${ }^{12}$ Arimura, T.H., Hibiki A., Johnstone N., Anempirical analysis of environmental R\&D: what encourages facilities be environmentally innovative? [in:] N. Johnstone (red.) "Environmental Policy and CorporateBehaviour", Edward Elgar, Cheltenham 2007.

${ }^{13}$ Mickwitz P., Hyvättinen H., KivimaaP., The role of policy instruments in the innovation and diffusion of environmentally friendlier technologies: popular claims versus case study experiences, "Journal of Cleaner Production" 2007, Vol.16.

${ }^{14}$ Rennings K., Rexhäuser S., Long-term impacts of environmental policy and eco-innovativeactivities of firms, ZEW Discussion Papers 10-074, ZEW -Zentrum für Europäische Wirtschaftsforschung / Center for European Economic Research 2010.

${ }^{15}$ Szpor A., ŚniegockiA., Ecoinnovations in Poland. Current situation, developmental barriers, possibilities of support, IBS Warszawa 2012

${ }^{16}$ Kemp R., Volpi M., The diffusion of clean technologies: a review with suggestions for future diffusion analysis, "Journal of Cleaner Production" 2008, vol. 16 (1)
} 
- organisational innovations (organisational innovations) - new environment management (e.g. according to ISO 14001 norm, EMAS), management based on the life cycle assessment concept (LCA) and cooperation between enterprises.

- product and service innovations - comprising changes at the stage of design and product or service generation,

- "green" system innovations - alternative production and consumption systems, friendlier to the environment than the ones used so far, e.g. implementation of renewable energy sources.

Of course, the field or fields for innovation creation depends on the enterprise specificity. Innovation implementation is a complex process dependent on many diverse factors, internal and external in relation to the enterprise. An innovation process is a repetitive cycle of many activities ${ }^{17}$ :

- finding ideas,

- testing and implementation of a selected project,

- promotion and launching a product into the market,

- creation of new uses on the basis of the innovations used earlier.

Table 1. Stages of innovation implementation in a company

\begin{tabular}{|l|l|}
\hline I & defining the problem \\
\hline II & searching for possible solutions \\
\hline III & designing, testing \\
\hline IV & implementation \\
\hline V & monitoring, correcting \\
\hline VI & entering the market, selling \\
\hline
\end{tabular}

Source: Sztucki M. Stages of innovation implementation in a company (http://www.naukaigospodarka.pl/index.php?option=com_content $\&$ view=article\&id=156:etapy-procesuinnowacyjnego-w-przedsibiorstwie\&catid=39:artykuly\&Itemid=78\& lan $\mathrm{g}=\mathrm{pl}$ )

Also, what is important is the issue of knowledge and the transformation of particular ideas into innovative products or services. Two models of innovative process are the most frequently mentioned in the field: supply governed innovations and innovations stimulated by the market needs.

As far as the former group is concerned, the innovations are created in the areas of science, and then introduced to economy. Certainly, enterprises must be prepared organisationally and technically for the new systems implementation.

In the later group, new solutions are determined by the needs. In this case, as opposed to the above-mentioned, it is the market which decides about the creation of new innovations. The eco-innovation factor is the consumer's demand. Awareness and knowledge of the society, e.g. as regards clean technologies, determines the innovations implementation $^{18}$.

\footnotetext{
${ }^{17}$ Gaczek W.M., Komorowski J.W., Human and social resources of the region as a factor of economy development based on knowledge, [in:] "Innovations in the Region Development”, W.M. Gaczek (ed.), Research Papers of the University of Economics in Poznan, No. 57, The University of Economics in Poznan Publisher, Poznan 2005.

${ }^{18}$ Urbaniak W., Innovations in Waste Management, Materials of the $18^{\text {th }}$ International Environmental Protection Congress ENVICON 13-14 October 2014 in Poznan, ABRYS LLC Publishing House, Poznan 2014
} 
Apart from the above-mentioned factors, another group of important factors are external ones, related to public institutions and their development policy. Environment protection or tax policy may have great impact on companies' eco-innovativeness ${ }^{19}$.

In order for an enterprise to dynamically develop ecological activity, the following conditions have to be met:

- achievement of adequate level of knowledge and staff awareness about the necessities and possibilities of pro-ecological activities,

- making entrepreneurs aware of the benefits and necessity of pro-ecological activities,

- shaping an adequate organizational and technological infrastructure to support the process of transformation of ideas into eco-innovations,

- training for entrepreneurships on the possibilities of financial aids from funds for innovations related to environment protection,

- training, directing and motivating staff to engage more in the environment protection activities.

\section{BARRIERS RESTRICTING DEVELOPMENT OF ECO-INNOVATIONS}

At particular stages of development and implementation of eco-innovations, various difficulties may occur, e.g. organisational, economical, informational or motivational. Generally, eco-innovations meet the same barriers as any other innovations, however, often they are intensified by the markets' failures within the field of environment protection $^{20,21}$ (Figs. 1-2).

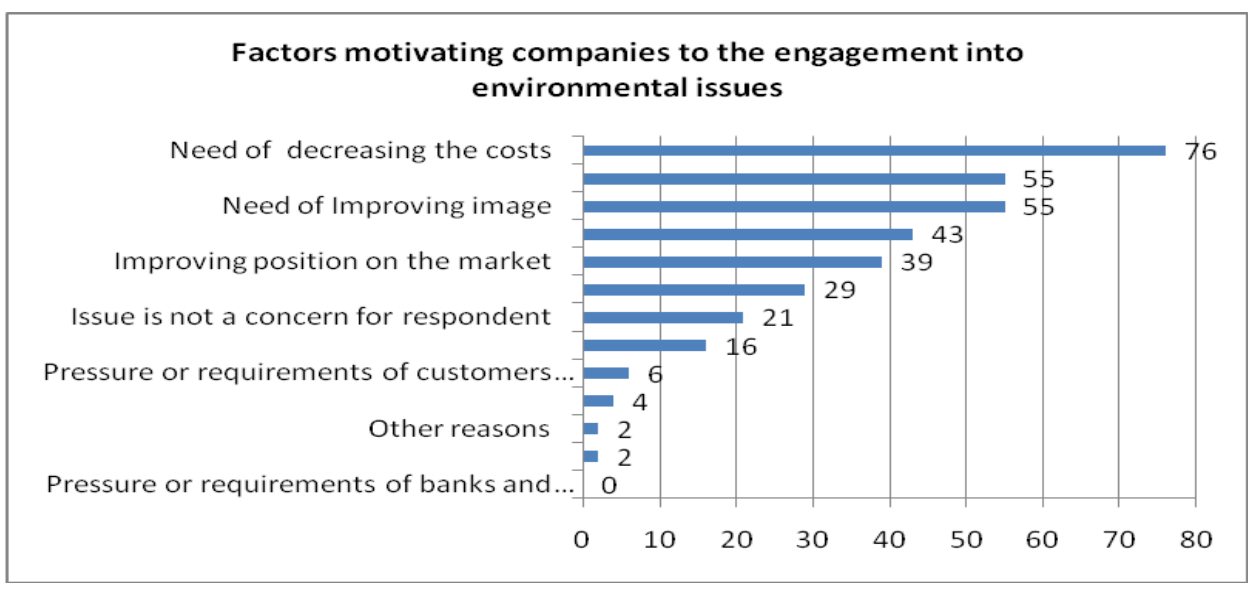

Fig 1. 2 Factors influencing the choice and hindering the implementation of eco-innovation in Poland,

Source: Foundation Partnership for the Environment (2010)

\footnotetext{
${ }^{19}$ Horbach J., Indicator systems for sustainable innovation, Physic, Heidelberg 2005

${ }^{20}$ Jaffe A.B., Newell R.G. Stavins R.N., A tale of two market failures: Technology and environmental policy, "Ecological Economics" 2005. 54 (2-3).

${ }^{21}$ Johnson K.N. Lybecker K.M., Innovating for an uncertain market: A literature view of the constraints on environmental innovation, Colorado College Working Paper 2009-06, Department of Economics and Business, Colorado College 2009
} 


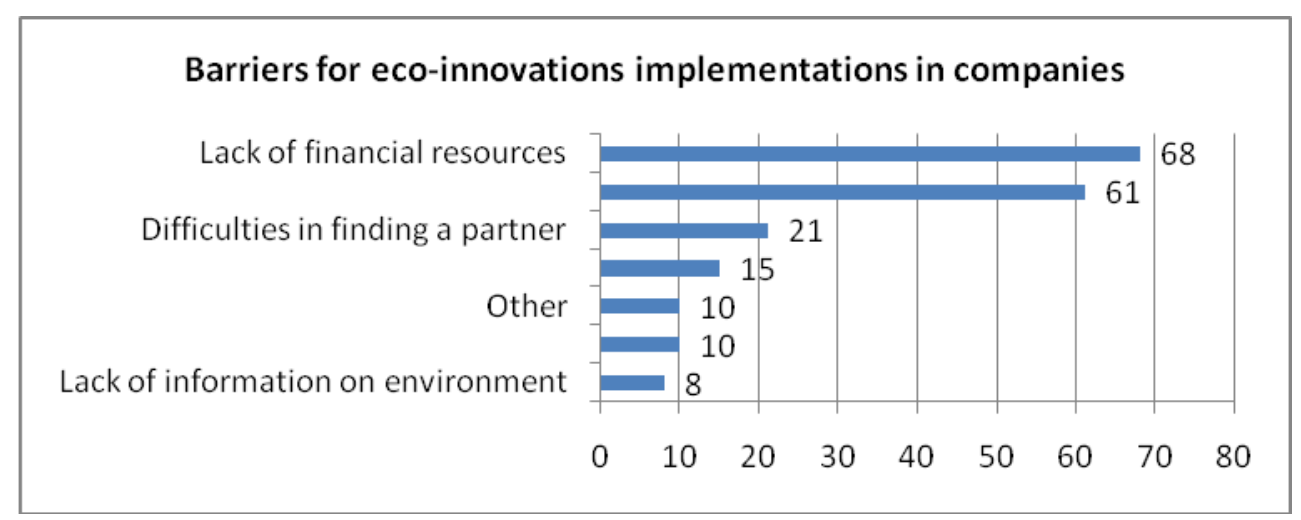

Fig 2. Barriers for eco-innovation implementations in companies

Source: Foundation Partnership for the Environment (2010)

The most important barriers hindering the eco-innovations implementation in companies are the following factors:

- economical - lack of company's own financial means, lack of external financing, high interest rates of loans for innovations, financial risk related to uncertainty of refund of invested funds, let alone obtaining economical benefits, etc.,

- legal - frequent changes of legislation causing market's uncertainty and discouraging from investment, unclear, changeable laws and regulations concerning environment protection, etc.,

- marketing - lack of market needs identification, uncertainty of sale of new, innovative products, etc.,

- technological - inadequate research and developmental base, lack of flow of information about possible technologies or products, limited accessibility of technologies, lack of sufficient support from the research centers,

- staffing - problems with management competences, lack of adequate skills for ecoinnovation processes management, lack of prepared, appropriately educated and experienced staff, lack of conviction and

- discouragement for risk taking in the field of eco-innovation.

Moreover, a group of entrepreneurs are not aware of all the effects of a company's interference with the natural environment, and therefore, they do not notice the need of environment protection solutions being implemented. A research study conducted by the Partnership for the Environment Foundation in 2008 on the influence of SME on the environment, with the main aim of determining the degree of ecological awareness in the researched companies and their readiness to undertake steps for environment protection, showed that $68 \%$ of respondents considers the influence of their activities on the environment as minimal.

For comparison, the research results obtained by the same organisation in 2004 on the reasons for undertaking pro-ecological activities by SME in Poland showed that over $3 / 4$ of the researched companies considers that the influence of their activities on the environment is either small or very small. It proves that ecological awareness among entrepreneurs raises minimally. There is, however, a small group of entrepreneurs (7\% of respondents) convinced that their activity does not influence the environment in any 
way. ${ }^{22},{ }^{23}$ Often, even, the management staff do not have adequate knowledge concerning the duties stemming from legal regulations concerning the environment protection. It results from the complicated, unclear and often changing regulations or lack of adequate education and staff trainings. It must be emphasised, however, that entrepreneurs not always notice the benefits of pro-ecological solutions, e.g. savings from the improvements of the natural resources use or from the implementation of pro-ecological products to markets. For many companies, eco-innovation projects are too uncertain and their implementation too expensive and time-consuming ${ }^{24}$.

The facts that innovations give the possibility of a company's functioning cost reduction, as well as more effective use of its supplies, were most often indicated by the respondents of the research studies carried out by T.B. Kalinowski. They were noticed by nearly $46 \%$ and $50 \%$ of the respondents respectively. Nevertheless, every third respondent indicated the limited financial sources as the basic barrier for innovation implementation. ${ }^{25}$

Moreover, research studies show that entrepreneurs running small businesses, often are not competent and do not have enough time for data collection and analysis necessary for the implementation of the innovative solutions.

All the above barriers are the most noticeable in the case of EMS which dispose of small funds and have even smaller possibilities of obtaining useful knowledge and experience in comparison to big companies.

\section{SUMMARY}

The analysis of the extent to which innovations are implemented allows to observe that still, the greatest issue faced especially by small and medium-sized Polish enterprises is the cost of the implementation.

It must be underlined that in Poland such enterprises are the greatest group and their development is of priority in the programme of local development. SME play an important role in every market economy, as they provide job vacancies and generate significant part of GDP. Unfortunately, a weak financial condition of SME, inconsistent financing system for the environment protection activities, unstable financial conditions, lack of marketing skills, concerns and unwillingness to take risk related to innovations are the basic barriers against eco-innovations implementation. Institutional hindrances comprise content and systemic weaknesses in the effective use of financial aid or unsatisfactory knowledge of patents and copyrights, etc. Another reason of low innovativeness mentioned by entrepreneurs is, among others, the great number of legal regulations and their frequent changes, which discourage small enterprises from undertaking additional actions. It must be emphasised that in small enterprises, the

\footnotetext{
${ }^{22}$ Kornecki J., Michaliszyn B., Krupanek J., Ratman-Kłosińska I., Banasiak M., Pochroń A., Kondrat P., Jagusztyn-Krynicki T., Czyż P., Wolińska I., Pylak K., SME Potential in the Field of New Innovative Products Creation - Pro-ecological Solutions, Order finalised from the EU Funds of Regional Development, 2008.

${ }^{23}$ Łunarski J., Eco-innovativeness in the Production Processes Reorganisation, [in:] Woźniak L., Strojny J., Wojnicka E. (ed.) "Eco-innovations in the Practice of SME Functioning", Polish Agency for Enterprise, Warsaw.2010.

${ }^{24}$ Sudoł S., Enterprise, The Basics of Enterprise Studies, TNOiK, Torun 1999

${ }^{25}$ Kalinowski T. B., Entrepreneurships' Management and Quality Management Systems, Wolters Kluwer, Warszawa 2010.
} 
implementation of new solutions depends, to a large extent, on the entrepreneur him- or herself. It is them who is responsible for the creativity and ideas generation, for staff stimulation for activity and for the company's preparation for innovations.

A great part of SME managers believes that eco-innovation implementation is risky and too expensive, which may be particularly significant both in the innovation creation and in the commercialisation processes. The most serious barrier for entrepreneurs is the uncertainty of the eco-innovation investment cost return and long time needed for $\mathrm{it}^{26,27,28}$. Some remedy for this lack of resources and risk reluctance attitude is offered by actions within EU funded programs that are oriented on direct support of SMEs ${ }^{29,30}$. The literature data indicates that, besides the financial support, in order to overcome the eco-innovation implementation restrictions, actions should be undertaken in order to raise awareness of the necessity of eco-innovations. Substantial for this are the processes of learning and gaining knowledge on the necessity of natural environment protection.

\section{REFERENCES}

[1] Arimura, T.H., Hibiki A., Johnstone N.2007. Anempirical analysis of environmental R\&D: what encourages facilities be environmentally innovative? [in:] N. Johnstone (red.) "Environmental Policy and Corporate Behaviour". Cheltenham: Edward Elgar.

[2] Bombiak E.2003. "Desirable pattern. Company functioning models in the $21^{\text {st }}$ century". Personel 3:7-8.

[3] Fussler C., James P.1996. Eco-innovation: A Breakthrough Discipline for Innovation and Sustainability. London: Pitman Publishing.

[4] Gaczek W.M., Komorowski J.W. 2005. Human and social resources of the region as a factor of economy development based on knowledge. Innovations in the Region Development, W.M. Gaczek (ed.), Research Papers of the University of Economics in Poznan, 57, The University of Economics in Poznan Publisher.

[5] Grudzewski M.W., Hajduk I.K. 2008. Technology Management. Advanced Technologies and their Commercialisation. Warszawa: Difin.

[6] Horbach J.2005. Indicator systems for sustainable innovation. Heidelberg: Physica-Verlag.

[7] Jaffe A.B., Newell R.G. Stavins R.N.2005." A tale of two market failures: Technology and environmental policy". Ecological Economics 54: 2-3.

[8] Johnson K.N. Lybecker K.M. 2009. Innovating for an uncertain market: A literature view of the constraints on environmental innovation, Colorado College Working Paper 2009-06, Department of Economics and Business, Colorado College .

[9] Kalinowski T. B.2010. Entrepreneurships' Management and Quality Management Systems. Warszawa: Wolters Kluwer.

[10] Kanerva M., Arundel A., Kemp R.2009. Environmental innovation: Using qualitative models to identify indicator for policy, United Nations University Working Papers Series, Maastricht.

[11] Kemp R., Volpi M. 2008. "The diffusion of clean technologies: a review with suggestions for future diffusion analysis”. Journal of Cleaner Production 16 (1):14-21

\footnotetext{
${ }^{26}$ Nowakowska A., Regional Context of the Innovation Processes, [in:] Nowakowska A. (ed.) "Building Regional Innovation Competences", Biblioteka Publishing House, Lodz 2009.

27 Nowakowska A., Regional Dimension of Innovation Processes, University of Lodz Publishing House, Lodz 2011.

${ }^{28}$ Ryszko A., Motivation and Barriers of the Eco-innovative Activity of Enterprises in Poland, "Modern Management Review" 2014, Vol. XIX, 21.

${ }^{29}$ Bombiak E., Desirable pattern. Company functioning models in the $21^{\text {st }}$ century, "Personel" 2003, No. 3.

${ }^{30}$ Nitkiewicz, T., Assessment of EU Structural Funds Contribution to Eco-Innovation Implementation in Slaskie Voivodship, Problemy Eksploatacji (Maintenance Problems) 4(87) 2012
} 
[12] Kornecki J., Michaliszyn B., Krupanek J., Ratman-Kłosińska I., Banasiak M., Pochroń A., Kondrat P., Jagusztyn-Krynicki T., Czyż P., Wolińska I., Pylak K. 2008. SME Potential in the Field of New Innovative Products Creation - Pro-ecological Solutions, Order finalised from the EU Funds of Regional Development.

[13] Łunarski J. 2010. Environment Management Systems. Rzeszow: Technical University of Rzeszow Publishing House.

[14] Łunarski J.2010. "Eco-innovativeness in the Production Processes Reorganisation". [in:] Woźniak L., Strojny J., Wojnicka E. (ed.) Eco-innovations in the Practice of SME Functioning. Warsaw: Polish Agency for Enterprise.

[15] Mickwitz P., Hyvättinen H., Kivima P.2007." The role of policy instruments in the innovation and diffusion of environmentally friendlier technologies: popular claims versus case study experiences". Journal of Cleaner Production 16:162-170.

[16] Nitkiewicz, T.2012." Assessment of EU Structural Funds Contribution to Eco-Innovation Implementation in Slaskie Voivodship". Maintenance Problems 4(87):48-55.

[17] Nowakowska A.2009. "Regional Context of the Innovation Processes" [in:] Nowakowska A. (ed.) Building Regional Innovation Competences. Lodz: Publishing University of Lodz.

[18] Nowakowska A. 2011. Regional Dimension of Innovation Processes, Lodz: University of Lodz Publishing House.

[19] Reid A., Miedziński M. 2008. Eco-innovation. Final Report for sectoral innovation watch, Technopolis Group.

[20] Rennings K., Rexhäuser S. 2010. Long-term impacts of environmental policy and ecoinnovativeactivities of firms, ZEW Discussion Papers 10-074, ZEW -Zentrum für Europäische Wirtschaftsforschung / Center for European Economic Research.

[21] Ryszko A. 2014. "Motivation and Barriers of the Eco-innovative Activity of Enterprises in Poland". Modern Management Review XIX, 21.

[22] Sudoł S.1999. Enterprise. The Basics of Enterprise Studies. Torun: TNOiK.

[23] Szpor A., Śniegocki A. 2012. Ecoinnovations in Poland. Current situation, developmental barriers, possibilities of support. Warszawa :IBS

[24] Urbaniak W. 2014. Innovations in Waste Management, Materials of the $18^{\text {th }}$ International Environmental Protection Congress ENVICON 13-14 October 2014 in Poznan. Poznan: ABRYS LLC Publishing House.

[25] Żołnierski A. 2009. Report on the states of SME in Poland in the years 2007-2008, Polish Agency for Enterprise, Warsaw.

\section{MOŻLIWOŚCI I OGRANICZENIA WPROWADZANIA EKOINNOWACJI W MALYCH PRZEDSIĘBIORSTWACH}

Analiza poziomu wprowadzania innowacji pozwala stwierdzić, że nadal dużym problemem szczególnie dla małych przedsiębiorstw są koszty ich wprowadzenia. Stwierdzenie to znajduje odzwierciedlenie w wynikach badań jakościowych oraz ilościowych, które przedstawiono w artykule. Słaba kondycja finansowa przedsiębiorstw, szczególnie małych i średnich, niespójny system finansowania przedsięwzięć z zakresu ochrony środowiska, niestabilne warunki finansowe, brak umiejętności marketingowych oraz obawa i niechęć do ponoszenia ryzyka związanego z podejmowaniem przedsięwzięć innowacyjnych są podstawowymi barierami wprowadzania ekoinnowacji. Wśród barier instytucjonalnych wymieniane są słabości merytoryczne i systemowe w efektywnym wykorzystaniu pomocowych funduszy czy niedostateczna wiedza o patentach, prawach autorskich itp. Koleją $\mathrm{z}$ przyczyn niskiej innowacyjności wymienianych przez przedsiębiorców jest m.in. duża ilość przepisów prawnych częste ich zmiany co zniechęca małe przedsiębiorstwa do podejmowania dodatkowych działań. Należy podkreślić, że w 
małych przedsiębiorstwach wprowadzanie nowych rozwiązań uzależnione jest w dużym stopniu od postawy samego przedsiębiorcy. To on przede wszystkim ponosi ciężar kreowania pomysłów, pobudzania pracowników do aktywności oraz przygotowywania przedsiębiorstwa do wdrożenia innowacyjnych rozwiązań.

Analiza danych literaturowych wskazuje, że w celu pokonania barier ograniczających wdrażanie ekoinnowacji powinny być podjęte działania przede wszystkim w zakresie zwiększenia świadomości potrzeby wprowadzenia ekoinnowacji. Fundamentalne znaczenie mają procesy uczenia się, zdobywania wiedzy na temat konieczności ochrony środowiska naturalnego. Prawidłowe zarządzanie środowiskowe wymaga również uruchamiania nowych instrumentów i udoskonalania procedur pozwalających na wprowadzanie przez przedsiębiorców przyjaznych środowisku rozwiązań.

Slowa kluczowe: innowacje, małe przedsiębiorstwa, bariery, zarządzanie środowiskowe, proekologiczne działania.

\section{DOI: 10.7862/rz.2016.mmr.50}

Tekst złożono w redakcji: październik 2016

Przyjęto do druku: grudzień 2016 